\title{
Internet resources for liberalism
}

\author{
By Rod Bustos and Roxann Bustos
}

\section{How to be "conservatively incorrect" on the Net}

$\mathbf{T}$ he tendency of people to separate into political factions has not only been the cause of much of the world's strife, but has generated many fascinating discussions as well. In recent months it has also inspired many Internet sites. As Thomas Jefferson noted, "Men by their constitutions are naturally divided into two parties." It seems appropriate, to complement the listing of "Internet resources for conservatism" in the July/August CERL News with a listing of resources for liberalism. Libertarian and radical left resources have been excluded.

Although the conservative movement has been on the upswing in recent years, liberalism is hardly dead. The vitality of the liberal movement in the U.S. today can be seen in the number and variety of Internet resources available propounding liberal ideas.

\section{Electronic journals}

- The American Prospect. Billed as "a journal for the Liberal Imagination," this electronic version of American Prospect magazine offers insightful articles on liberal issues and concerns. Access: http://epn.org/prospect.html.

- Conservatively Incorrect. This newsletter offers hard-hitting articles on the conservative agenda written in a humorous style. Includes links to related sites. Access: http:// turnpike.net/emporium/H/HR/index.htm.

- The Liberal Avenger. This independently produced newsletter features well-writ- ten articles and commentary on liberal issues. Access: http://www.lcsc.edu/ mackenzi/ avenger.html.

- MojoWire. Log onto this online edition of Mother Jones and find out what's bugging America's liberals. Access feature-length articles and links to related resources. Access: http:// www.mojones.com.

\section{World Wide Web resources}

- The Anti-Rush Limbaugh Page. Fed up with Rush Limbaugh's daily ranting and raving? Check out this site by the creator of the Web's Turn Left to see Limbaugh's 35 Unquestionable Truths refuted, the Rush Limbaugh quote of the day, and the 18 commandments of the conservative radio host. Access: http://www. cjnetworks.com/ cubsfan/rush/antirush.html.

- Brian's Progressive Pages. Formerly known as the Left Side of the Web, this site provides links to many resources for progressive activists. Includes sites that keep tabs on the militia movement, as well as a variety of liberal organizations, journals, and newsgroups. Access: http://paul.spu.edu/ sinnfein/ progressive.html.

- Democratic National Committee (DNC) Home Page. Although liberals may not be as closely aligned with the Democratic Party as conservatives are with the Republicans, liberals traditionally identify themselves with various important issues espoused by the Democrats. The DNC homepage provides a means for users to join the organization, find out about Democratic groups in their area, keep up with important party news, and connect to related Web sites. Access: http://www.democrats.org/.

Rod Bustos is a public services librarian at Swilley Library, Mercer University, Atlanta, e-mail: bustos_ra(0)mercer.edu; Roxann Bustos is coordinator of reference services at Reese Library, Augusta College, e-mail: rbustos@acad2.ac.edu 
- Majority '96. The Majority '96 page is a grassroots effort dedicated to winning back a Democratic majority in key U.S. House and Senate offices. It provides links to important Democratic sites, lists targeted races for the $1996 \mathrm{elec}$ tion, and contains information about the organization's Cybergazette newsletter. Access: http://www.cais.com/majority96/.

- Senator Edward Kennedy's Home Page. Sen. Edward Kennedy has long been a strong supporter of liberal causes in the U.S. Senate. He continues this tradition via a homepage that gives information about him, his record, and on getting involved with the political process. Access: http://www ai.mit.edu/ projects/iiip/Kennedy/homepage.html.

- Turn Left (the Home of Liberalism on the Web). Perhaps the premier place for liberal information on the Web, this well-designed page, created by Mike Silverman, provides links to a wide variety of excellent liberal sites, as well as basic information about liberalism today. Access: http://www.cjnetworks.com/ -cubsfan/liberal.html.

\section{Organizations}

- The Abortion Rights Activist Home Page. This Web site provides information for all those who work to preserve women's access to abortion. The page provides links to information about abortion, clinic violence, legislation, and more. Access: http://www.cais. $\mathrm{com} / \mathrm{agm} / \mathrm{index}$.html.

- Anti-Defamation League Home Page. Since 1913 the Anti-Defamation League (ADL) has fought against anti-Semitism in particular and all forms of hatred and bigotry in general. This Web site provides detailed information about the ADL, press releases and reports issued by the organization, and human relations materials. Access: http://www.adl.org.

- LaborWEB: The AFL-CIO's Home Page. This well-designed site offers details about the AFL-CIO, current information on labor disputes, links to union organizations on the Web, and stories from the latest edition of the $A F L-C I O$ News On Line. Access: http://www.aflcio.org.

- NAACP Home Page. The historical guardian of civil rights, the NAACP has created a homepage that provides a means for indivicluals to inform themselves about the organization and to become members. Access: http: //www.bin.com/assocorg/naacp/naacp.htm.

- National Organization for Women (NOW) Home Page. Closely identified with the feminist movement, NOW offers this homepage to provide women with a central site for information on the organization, as well as important issues such as abortion rights and domestic violence. Access: http://now.org/now/ home.html.

\section{Electronic discussion groups}

- Democratic National Committee Listservs. The Democratic National Committee (DNC) recently announced a series of electronic mailing lists that will send interested individuals the latest information about the Democratic party via electronic mail. The lists include Democratic News, Democratic News Digest, and Democratic Events. To subscribe to any of these lists send a message to majordomo@ democrats.org with "subscribe [name of list]" in the body of the e-mail.

- Leftnews: Left News and Events. This list provides timely announcements of important news of interest to leftists in both the U.S. and abroad. Subscribe: Send the message "sub LEFTNEWS your name” to listserv@cmsa. berkeley.edu.

- Left-Org: Democratic Left Organization Discussions. Based at the same university in Berkeley as the previous list, this listserv offers subscribers the opportunity to discuss issues of interest to the Democratic Left. Subscribe: Send the message "sub LEFT-ORG your name" to listserv@cmsa.berkeley.edu.

\section{Usenet groups}

- Newsgroups like alt.politics.democrats.d and misc.activism.progressive provide access to freewheeling discussions on a wide variety of topics, some of interest to liberals. Please see your local systems administrator to find out about access at your institution.

\section{Gophers}

- American Civil Liberties Union (ACLU). Once all the rage on the Internet, gophers are rapidly being phased out to make way for showier Web-based resources. One liberal group that does still maintain a gopher presence is the ACLU. This site provides a wealth of information on the organization itself, as well as on related publications. Access: gopher:// gopher.nyc.pipeline.com/11/society/aclu.

Autbor note: The resources discussed in this article can be accessed directly at http://www. mercer.edu/ -bustos_ra/liberal.htm. 